\title{
The sound of music or the history of Trump and Clinton family singers: Music branding as communication strategy in 2016 presidential campaign
}

\author{
Lluís Mas \\ Department of Communication \\ Pompeu Fabra University (Spain) \\ lluis,mas@upf.edu
}

Maria-Rosa Collell

Department of Linguistics and Communication

University of Girona (Spain)

mrosa.collell@udg.edu

Jordi Xifra

Department of Communication

Pompeu Fabra University (Spain)

jordi.xifra@upf.edu

\begin{abstract}
Sound branding has been eventually used to recognize the brand and associated with certain values. Despite being a powerful branding resource, especially in political campaigns, music is still underrated in both practitioners' and researchers' fields of action. The objective of this study is to analyze the potential of music to conduct a political branding strategy by itself. Six campaign ads from the 2016 US elections are analyzed acoustically and semiotically to gain insights on the music branding significance. The results suggest that both Clinton and Trump campaigns used music strategically to communicate values in the emotional arena. In particular, Trump's music conducted brand associations and personality strategy based on the construction of a war hero taking action to save his homeland in times of crisis. Music can transmit brand values through interactions based on emotional experiences. The connections stablished in this article between music and branding can be taken as a model for
\end{abstract}


practitioners to design future political strategies and researches to test brand constructs within the music branding framework.

Keywords: sound branding; music branding; political brands; 2016 US elections; brand associations; brand personality.

The use of music as a persuasion tool traces us back to the origins of television advertising. The evolution of music in advertising runs parallel to the progress made in the state of the art on communication models and strategies. These strategies were initially based on explicit and memory-based messages supported by an insistent and simplistic melody, along with music lyrics describing the brand and product. However, music's communication potential goes far beyond. Music is said to be the language of human emotions, thus music can be easily used to create brand associations through emotional experiences (Dubé, Chebat \& Morin, 1995; Alpert, Alpert \& Maltz, 2005). Undoubtedly, music can be a powerful branding strategy (Brodsky, 2010). Yet, thus far, both researches and practitioners are still focusing on recognition and recall effects of music in jingles, piped-in music (music in spaces) and background music in advertising campaigns.

Political communication is a pioneer field in the use of music to raise emotions to humanize and characterize the candidate (Murphy, Schurmann \& Moscardo, 2013). During political campaigns, music is usually employed to create atmospheres and environments around the candidate. Currently, political parties present the candidate as a brand, and so the strategic power of music is increasing. Music in itself has the capacity to promote associations between a person-brand and commonly known archetypes, characters, types of actions in all sorts of contexts, among those that share norms, traditions and culture. The most immediate way to stablish these connections is through the connection between music genres and target ages. Anyhow, the strategic use of this element needs to be tightly controlled as any music and any music sound will inevitably convey meanings (Simmons, 2005),

The 2016 US presidential election race was a highly controversial and polarized campaign between two candidates —-Donald Trump and Hillary Clinton- who used 
music branding intensively. As widely known, Trump won the elections despite expectations and desires from the American Government, the main world and organization leaders, and the powers that be in general. Trump took the campaign to a rather personal, coarse and even rude level. In today's personalization of politics (Nusselder, 2013), the person-candidate acts as a branded citizen that gets in touch with other citizens-potential voters (Guzmán, Paswan \& Steenburg, 2015; Cwalina \& Falkowski, 2015). The candidate is the flagship of political campaigns, thus political branding attributes can be crucially applied to build the candidate-brand (Aaker, 1997). In this regard publics can strongly bond with brands by a constant interaction and the enhancement of each other's identity (Belaid \& Temessek Behi, 2011). The brand attachment between the political brand and users is defined as an affective and emotional bond (Whan Park, Macinis \& Priester, 2006). Thus, brands are emotional constructs to which music can make a great contribution as a powerful emotional tool in contemporary society (Lantos \& Craton, 2012). However, the contribution of music to the branding strategies in political campaigns is uncertain and has not paid much attention by political communication scholars.

The aim of this study is to analyze what political branding constructs can be built by music, and to gain insights on how music features are strategically connected with these constructs. Our starting hypothesis is that music was used strategically in the 2016 US campaign to raise emotions and transmit brand values of the candidate brand. Two research questions on how music was used in this campaign are formulated to lay foundations on this hypothesis. The theoretical framework has two parts. Firstly, music branding is reviewed as part of sound branding strategies. Secondly, some basic branding constructs are reviewed as a music branding proposal to be tested.

\section{MUSIC BRANDING}

Music branding is the use of music as part of a branding strategy. The study of music within the branding framework is rather new. Thus far, research has mainly focused on music from commercials (Park \& Young, 1986), audio logos, jingles and voices (Jackson, 2004; Venkataraman, 2007; Bollue, 2015; Gustafsson, 2015). However, the significance of sound to identify, experience, connect and signify brands is increasing (Schmitt, 2012). 
Sonic branding is the strategic use of sound to communicate the identity and values of a brand (Groves, 2007; Krishnan, Kellaris \& Aurand, 2012). Sound is a rather peculiar human sense as it functions continuously $24 / 7$ with a $360^{\circ}$ range since the third month of pregnancy. Sound is the most precise and emotional sense. Particularly, music is a human mean of expression that has been around for centuries. As an all-involving resource, sound is used for the publics to recognize the brand in different touchpoints (Jackson, 2004). The touchpoints are the diverse and multilayered contexts and situations in which brands and consumers interact: retail stores, television advertising, digital media, sponsored events or political campaigns.

Sound has been primarily employesd to recognize the brand and associate it with certain values (Jackson \& Jankovich, 2013). Recently, studies are showing that sound can attain other goals such as a consumer's direct response, brand reputation and brand image (Farhana, 2012), and recall and emotional experiences (Spence, Shankar \& Blumenthal, 2010; Spence, 2008, 2012). According to Klink (2000: 145), an effective sound brand "should be recognizable, familiar, evoke positive affect and elicit meaning". Therefore, sound resources are used to convey the values of a brand meet the listener's cognitive and emotional processing (Vorster, 2015), create brand image and transmit brand attitudes (Argo, Popa \& Smith, 2010). According to Bonde and Hansen (2003), audio logo must have consistency and continuity, be distinctive, identifiable and "suitable ('fitting' or 'congruent') with regard to the attributes and values of the corporate brand" (p. 115).

The study of sound as a strategic resource is based on the characteristics of the four sound elements - voice, music, effects and silence. These elements are intrinsically embedded as music may contain sung or intoned voices, effects and silence. However, the presence of added effects and silence in music is still marginal; thus, research focuses on music itself and sung voice. The acoustic features of any melody given by musical instruments and voice can characterize music. These acoustic features have a meaningful and symbolic power. Machin (2011) tried to find evidences on how pitch range and melodic patterns are used to communicate underlying emotions. In essence, high pitched sounds are perceived as exciting and transmit happy emotions, while low pitched sounds are perceived as calm, sad and thoughtful emotions. The type of instruments used can also make a contribution on the emotional state. Piano is usually 
an introspective highly emotional instrument, while percussion is dynamic and determines the pace of action. String instruments create background sounds that have been widely used in movies, thus they have a great power to create mental images associated with film genres. Further, instrumentation is connected with gender. Drums and trombone connote masculinity and violin and flute connote femininity (Abeles \& Porter, 1978); brass wind instruments connote majestic (Bruner, 1990). Stereotypically, women would prefer softer musical styles such as mainstream pop while males would prefer harder styles such as hard rock.

Sung voices can either transmit emotions of the basis of pitch, intensity and timbre (Spence, Shankar \& Blumenthal, 2010), or transmit explicit messages through the use of lyrics (Zander, 2006; Ballouli \& Heere, 2015). Voice is the most harmonic sound as its spectrum ranges from 20 to $20000 \mathrm{~Hz}$, which, not by chance, is the ear's sensitivity range (Riding, Lonsdale \& Brown, 2006). In this vein musical fit is defined as the connections between knowledge structures raised by music and brands (North, Mackenzie \& Law, 2004), and it is determined by three elements, namely voice, lyrics and music genre (Zander, 2006; Ballouli \& Heeree, 2015).

Some studies have focused on brands and music genres. Brodsky (2010) found that different types of music genre could be consistently associated with two different brand cars -Cadillac and Chevrolet. Actually, the mood theory specifies that associations between music and users are determined by musical fit, music popularity and likability (Ballouli \& Heeree, 2015). Admittedly, music can easily raise classical conditioning associations. However, Brodsky's study goes beyond mere classical conditioning as results showed that attitudes and feelings towards these two brand personalities correlated with different types of music, so music should be strategically chosen to act as a link between the brand and the consumer.

Music likability has traditionally determined the selection of music in advertising (Rentfrow \& Gosling, 2003). It is well known that target variables such as age, gender or social class mediate music likability (Fox \& Wince, 1975). Besides, the music popularity connects the brand with its country of origin (North, Hargreaves \& McKendrick, 1999) and the musical fit depends on the type of product and the context of consumption (Zhu \& Meyers-Levy, 2005). Accordingly, Zander (2006) notes that the 
musical genres can be associated with product's attributes. For instance, a rock song could be easily associated with "power, speed and competitiveness of the car, whereas the classical piece might emphasize beliefs about its interior trim, luxury and elegance" (2006: 468).

A theoretical framework on psychology, semiotics, cultural studies and communication supports the significance of acoustic elements and musical fit. The music code is as much a natural mechanism of perception as a cultural mechanism (Fuzellier, 1965), especially when it comes to cultural industries such as Hollywood films. Generally, music perception can be explained by the rationale of Gestalt Theory (van Leeuwen, 1999). Most importantly, the western perception of music is based on the melody (pitch variation) as the figure that takes form within a background sound context (Schaffer, 1979; van Leeuwen, 1999). Further, regardless the type of genre, western music is characterized by symmetry, clarity, goodness-of-form, proportion, balance and harmony (Reber, Schwarz \& Winkielman, 2004). Thanks to this semiotic and perceptive code, music is interpreted homogenously in a given culture (Winkielman, Schwarz, Fazendeiro \& Reber, 2003).

Finally, on the basis of the semiotics of sound (van Leeuwen, 1999), Bonde and Hansen (2013) argue that visual modality cues can be corresponded with sonic modality cues. Notably, color saturation is related with pitch range: the lighter, clear and gleaming the color, the more arising, exciting and optimistic; and the darker and saturated the more calm, relaxing and sad. These analogies can be applied to graphical logo, corporate colors and shapes, product features and so on. But the significance power of sound goes much further. In this regard mental imaginary is a well-documented psychological construct defined as the image that comes to people's mind when processing non-visual information (Paivio, 1986; Miller \& Marks, 1992; Schwartz, 1999). In other words, a mental image is the capacity "to see with the eye of mind, listen with the ear of the mind" (Kosslyn, Ganis \& Thompson, 2010: 3). This concept is crucial in sound branding. Sonic logo is defined as "the auditory analog of a visual logo" (Krishnan et $a l ., 2012:$ 276). And basic acoustics features such as frequencies, rhythm, intensities... are associated with product (size, shape, color, industry, model...), spaces, atmosphere, and so on, the study of which is opening up a compelling line of research on multisensory brand strategies. Mental images connect with van Leeuwen's semiotics of 
sound (1999) as they can be created by an agreed code of sounds that rhetorically refer to characters, actions or situations pictured by listeners when listening voices, effects and music. The soundscape concept is related to Fuzellier's seminal concept of sound atmosphere (1965) and Schaffer's concept of paysage sonore (1979). In both cases, sound is associated with a psychological tone. To some extent, soundscape can be seen as a cultural code shared by a cultural community.

Drawing on the fact that Trump and Clinton employed different types of music, the first research questions emerge:

RQ1: What sound elements, acoustic features and genres were being used by Trump and Clinton music campaign? What type of product and target were the music likability, fit and popularity referring to? What mental image were the two types of music referring to?

\section{BRAND CONSTRUCTS}

Music has not been considered as a branding construct thus far. As aforementioned, political communication has eventually considered music as a persuasive tool, either as part of an emerging strategy on sound branding or as sets of auditory features with an impact on information processing. This section lays some foundations on how music can connect itself with brandings constructs, so it should be taken as a theoretical proposal to which this study's findings may be insightful.

Back in the nineties Aaker (1991) defined brand equity as a "a set of brand assets and liabilities linked to a brand, its name and symbol, that add to or subtract from the value provided by a product or service to a firm and or to that firm's customers" (p. 15). These brand assets can be brand knowledge structures that consumers use for decision making and to establish a long term emotional affect with the brand (Keller, 1993). These structures are first of all based on brand recognition and brand associations (Aaker's, 1996). Brand associations help define what a brand is by knowing who uses it (an individual, a family, a society or a celebrity) in what contexts (place, time and atmosphere). Brand equity is part of long term all-encompassing strategy to be achieved by a coherent connection between the brand and the users' associations (Aaker, 1996). 
This connection is supported by identification processes of the users with the brand. A brand can actually be acquired because either the consumer feels identified with it or the consumer desires what the brand is. So it works both ways: the brand builds the users' identity and the consumer builds the brand's identity. Through a two-way iterative process of identification, the brand can symbolize an archetype, group, society or culture (Schmitt, 2012). A brand is a kind of metonym or inference with many implications and meanings, all of which are positioned in the consumer's mind.

Aaker (1997) found that brand personality is a well-established construct in the user's minds based on an anthropomorphizing process that makes users to conceive brands in terms of human personality dimensions. In particular, he found the following dimensions: sincerity, excitement, competence, sophistication and ruggedness. Further, Aaker, Fournier and Brasel (2004) argued that "relationships with 'exciting' brands were found to deepen in line with 'friendships' templates, whereas relationships with 'exciting' brands displayed characteristics of 'flings"” (Schmitt, 2012: 12).

As Aaker (1997) pointed out, consumer behavior researchers have focused on how the personality of a brand enables a consumer to express his or her own self, his or her ideal self or any specific dimensions of oneself through the use of a brand. To illustrate this, for instance, Tanqueray Gin personality tends to be described as a cool, hip, contemporary 25-year old, whereas Martini personality tends to be described as an intellectual, conservative, elegant, older man. The symbolic power of brands makes consumers to easily associate brands with celebrities or famous historical figures, even thinking of brands as if they were actual celebrities (Rook, 1985) or as if brands related to the own self (Fournier, 1998). In addition to these general brand knowledge structures initially defined by Keller (1993) and Aaker (1991), brands are currently multisensory constructs. Music, as part of a brand, has the power to create sensory experiences such as smell, touch or images (Roles, 2010).

In general, consumer-psychology brand constructs are closely related (Schmitt, 2012). Brand equity comprises several branding constructs such as brand attachment, brand loyalty or brand associations (Parker, 2012). On the basis of the music's potentiality to transmit cultural mental images of characters and contexts, we hypothesize a connection between music and the political brands' associations and personality (Roles, 2010). 
Sound becomes an experience in itself that reinforces brand associations and brand personality. So, the second research questions are:

RQ2. What knowledge structures did the two types of music employed in the two campaigns create? More specifically, what characters were being built by Trump and Clinton music through brand personality strategies? What brand associations were the two types of music stimulating?

\section{SAMPLE AND CASE STUDY}

This is a comparative case study in which 6 musical cuts (audiovisuals hereafter) from each candidate's campaign are collected and analyzed. The first audiovisual is the presentation of the candidates at their respective national conventions by their respective daughters, Ivanka Trump, July $21^{\text {st }}$, and Chelsea Clinton, July $28^{\text {th }}$, 2016. The two presentations follow the same pattern: each of their daughter's speech reaches a climax when they are referring to their respective father and mother, then the public start cheering and high intensity music announces the candidate appearance. This music runs for 60 seconds in the case of Trump and 143 seconds in the case of Clinton while they both greet and gesture (constantly smiling) at the crowd, family and friends.

The other audiovisuals are taken from their YouTube channel as each candidate has a YouTube channel with a very alike structure: first YouTube audiovisual ( $1^{\text {st }}$ YouTube), main YouTube audiovisual (Main YouTube) in a bigger window, and three other audiovisuals from the television campaign (spots 1,2, and 3) (see the case study description in Table 1). 
Table 1. Case study description.

\begin{tabular}{|c|c|c|c|c|c|c|}
\hline & Convention & 1st YouTube & $\begin{array}{l}\text { Main } \\
\text { YouTube }\end{array}$ & $1^{\text {st }}$ spot & $2^{\text {nd }}$ spot & $3^{\text {rd }}$ spot \\
\hline \multicolumn{7}{|l|}{ Trump } \\
\hline Duration & 60 & 40 & 122 & 30 & 15 & 42 \\
\hline Claim & $\begin{array}{l}\text { U.S.A ( } 5 \\
\text { times) }\end{array}$ & $\begin{array}{l}\text { Make } \\
\text { America great } \\
\text { again }\end{array}$ & $\begin{array}{l}\text { Do you wanna } \\
\text { see the United } \\
\text { States become } \\
\text { a winner? }\end{array}$ & $\begin{array}{l}\text { Make } \\
\text { America safe } \\
\text { again }\end{array}$ & $\begin{array}{l}\text { Make } \\
\text { America safe } \\
\text { again }\end{array}$ & I'm with you \\
\hline Structure & Discourse & Testimonies & Trump's cuts & Voiceover & Voiceover & [images] \\
\hline Content & $\begin{array}{l}\text { Candidate's } \\
\text { presentation }\end{array}$ & Leadership & $\begin{array}{l}\text { America in } \\
\text { crisis }\end{array}$ & $\begin{array}{l}\text { Fear \& } \\
\text { security }\end{array}$ & $\begin{array}{l}\text { Fear \& } \\
\text { security }\end{array}$ & Fear \& security \\
\hline \multicolumn{7}{|l|}{ Clinton } \\
\hline Duration & 143 & 60 & 60 & 134 & 193 & 203 \\
\hline Claim & $\begin{array}{l}\text { Thank you all } \\
\text { for an } \\
\text { amazing } \\
\text { welcome }\end{array}$ & $\begin{array}{l}\text { I'm voting for } \\
\text { Hillary } \\
\text { Clinton }\end{array}$ & $\begin{array}{l}\text { We need to } \\
\text { make sure that } \\
\text { they can be } \\
\text { proud of us }\end{array}$ & $\begin{array}{l}\text { It's you times } \\
\text { and I hope } \\
\text { you'll join me } \\
\text { on this } \\
\text { journey }\end{array}$ & $\begin{array}{l}\text { For this } \\
\text { country that } \\
\text { we love }\end{array}$ & $\begin{array}{l}\text { I may become } \\
\text { the first woman } \\
\text { president but } \\
\text { one of you is } \\
\text { next }\end{array}$ \\
\hline Structure & Discourse & Testimonies & $\begin{array}{l}\text { Trump's \& } \\
\text { Clinton's cuts }\end{array}$ & Testimonies & Obama's cuts & Documentary \\
\hline Content & $\begin{array}{l}\text { Candidate's } \\
\text { presentation }\end{array}$ & $\begin{array}{l}\text { Tolerance } \\
\text { (race, women) }\end{array}$ & $\begin{array}{l}\text { Future } \\
\text { generation \& } \\
\text { Trump's } \\
\text { intolerance }\end{array}$ & Live stories & $\begin{array}{l}\text { American } \\
\text { values }\end{array}$ & Ambient sound \\
\hline
\end{tabular}

These six units of analysis are approached from a two-step methodology. Firstly, sound features of music are described acoustically making use of Praat software (Boersma \& Weenink, 2014) to analyze average pitch (in $\mathrm{Hz}$ of a 4 seconds sample of each melodic structure), pitch range (in octaves within each melodic structure), contour (ascending, descending and cycle) (Krishna, 2012), and intensity (in dB); and MixMeister BPM Analyzer 1.0. (2016) to calculate rhythm (BPM, beats per minute). Besides, the use of voice lyrics and type of instruments are reported. Secondly, we define the genre of music (Gjerdingen \& Perrott, 2008), the mental images (Kosslyn et al., 2010), and the soundscape and background sounds (Schafer, 1977).

Findings on the significance of music will be discussed as a contribution to the candidates' strategies. Trump's and Clinton's brand strategies were rather different, if not opposed, which makes this a particularly interesting case study to lay foundations on music branding in political campaigns. In essence, Trump's campaign can be summed up in the WASHP model (White, Anglo-Saxon, Heterosexual, and Protestant). This general political strategy contrasts with Clinton's intercultural human model. Although both models can be said to define America and both are part of the social imaginary, the former is more stereotyped and thus it is rooted in the American imaginary through the American film industry of the last 50 years. Needless to say, the 
former is part of a conservative vision that values homogeneity and the old days whereas the latter is a more progressive vision that values diversity and modernity. Trump's campaign claims for a return to the origins while Clinton's focuses on the complexity of society. Trump is a well-known character that connects with a side of the American dream: work hard, make decisions, speak clear, do your way, do not be afraid, manage your life and money and be successful. Clinton represents the other side of the American dream: a country made of immigrants who were given the chance to be free and success in life as all humans have same opportunities when born.

\section{RESULTS}

Results focus on the acoustic and semiotic differences between the music from Trump and Clinton's campaigns. Firstly, we describe the results from the acoustic analysis (see Table 2). In general, the music employed by Clinton has higher pitch than the music employed by Trump. This evidence is found in the music employed to present the candidate during the national conventions (145 Hz in Trump's music and $434 \mathrm{~Hz}$ in Clinton's). In addition, although First YouTube and Main YouTube audiovisuals have similar average pitches, the three spots show significant differences, especially the first spot (131 Hz Trump and $411 \mathrm{~Hz}$ Clinton). Regarding the pitch range, differences are not very significant. Only the music from the convention shows great differences, with Trump's music presentation having a range of 1.6 octaves and Clinton's music presentation having 0.4 octaves. Besides, Trump's music had a consistent descending melodic pattern (except for the third spot, which is cyclic), while Clinton's music has an ascending contour in all elements but First YouTube and Second spot, which have cyclic contours.

The rhythm is also different in the two campaigns' music. Trump's music has an average rhythm of $114 \mathrm{bpm}$ while Clinton's music has an average rhythm of $122 \mathrm{bpm}$. The music in Trump's audiovisuals are always close to $100 \mathrm{bpm}$ with the exception of First YouTube audiovisual (149 bpm) and Main You Tube audiovisual (120 bpm); while the music in Clinton's audiovisuals ranges from 113 to $146 \mathrm{bpm}$ except for the YouTube audiovisual (105 bpm) and Main You Tube audiovisual (114 bpm). Also, the intensity of Trump's music presentation in the Republican convention is much softer (68 dB) than Clinton's music presentation in the Democrat convention ( $80 \mathrm{~dB})$. In the other audiovisuals, although with minor differences, music intensity from Clinton's 
campaign is higher in First YouTube, Main YouTube and First Spot audiovisuals, while it is a bit lower in the third spot (78 dB Trump and $69 \mathrm{~dB}$ Clinton). Notably, Trump's third spot had a peculiarity to take into account: the message was referring to Clinton the whole time.

Only one audiovisual has music with sung voice, namely the song employed in Clinton's presentation during the Democrat's convention. Regarding the type of instruments of the music from the two campaigns, Trump's campaign is dominated by string instruments while Clinton's music uses a much wider variety of instruments: piano, electronic music, electronic bass, and drums and wind instruments.

Table 2. Acoustic analysis of the music employed during the 2016 US elections campaign.

\begin{tabular}{lllllll} 
& CV & 1YT & M YT & 1S & 2S & 3S \\
\hline Trump & & & & & & \\
\hline Pitch (Hz) & 145 & 98 & 109 & 131 & {$[$ idem $]$} & 100 \\
Octaves & 1.6 & 0.5 & 0.8 & - & - & 1.5 \\
Contour & Desc. & Desc. & Desc. & Desc. & - & Cycle \\
Rhythm & 109 & 149 & 120 & 97 & 102 & 106 \\
Intensity & 68 & 57 & 65 & 67 & - & 78 \\
Voice lyrics & $\varnothing$ & $\varnothing$ & $\varnothing$ & $\varnothing$ & $\emptyset$ & $\varnothing$ \\
Instrument & String & String & String & String & String & String \\
\hline Clinton & & & & & & \\
\hline Pitch (Hz) & 434 & 104 & 98 & 411 & 146 & 146 \\
Octaves & 0.4 & 0.4 & & 0.8 & 0.03 & 1.5 \\
Contour & Asc. & Cycle & Asc. & Cycle & Asc. & Asc. \\
Rhythm & 113 & 105 & 114 & 127 & 126 & 146 \\
Intensity & 80 & 60 & 69 & 87 & 52 & 69 \\
Voice lyrics & Yes & $\varnothing$ & $\varnothing$ & $\varnothing$ & $\varnothing$ & $\varnothing$ \\
Instrument & Elec. & Piano & Piano & Elec. & Elec. & Wind \\
\hline
\end{tabular}

Secondly, results of the type of genre, mental image, soundscape and background sound are presented next. As shown in Table 3, Trump's campaign employs classical orchestral music while Clinton's campaign employs dance, classical minimalism or electronic (drum and bass, or experimental) music. Accordingly, the mental images created by the former focus on the character of a war hero in a patria in danger and in need of war action, while the mental images created by the later refer to youthful, modern, dynamic citizenship. Remarkably, Trump's third spot focuses on creating a negative image of candidate Clinton. To this end the music employed creates the mental image of a nightmare. 
The two campaigns' soundscape are homogeneous within themselves: Trump's music is focused on the soundscape of American patriotism, with the exception of the third spot that inspires horror movies, whereas Clinton's music is the contemporary American dream. Finally, the crowd effects are present in both candidate presentations in the conventions, plus in Clinton's third spot. Trump's first spot uses the effects of helicopters as the background sound of music.

Table 3. Social semiotics' analysis of the music employed during the 2016 US elections campaign.

\begin{tabular}{|c|c|c|c|c|c|c|}
\hline & CV & 1YT & M YT & $1 S$ & $2 S$ & $3 S$ \\
\hline \multicolumn{7}{|l|}{ Trump } \\
\hline Genre & $\begin{array}{l}\text { Classic. } \\
\text { Orches. }\end{array}$ & $\begin{array}{l}\text { Classic. } \\
\text { Orches. }\end{array}$ & $\begin{array}{l}\text { Classic. } \\
\text { Orches. }\end{array}$ & $\begin{array}{l}\text { Classic. } \\
\text { Orches. }\end{array}$ & [idem] $^{1}$ & $\begin{array}{l}\text { Classic. } \\
\text { Orches. }\end{array}$ \\
\hline $\begin{array}{l}\text { Mental } \\
\text { image }\end{array}$ & War hero & War hero & Challenge & War action & - & Nightmare \\
\hline Soundscape & $\begin{array}{l}\text { American } \\
\text { patriotism }\end{array}$ & $\begin{array}{l}\text { American } \\
\text { patriotism }\end{array}$ & $\begin{array}{l}\text { American } \\
\text { patriotism }\end{array}$ & $\begin{array}{l}\text { American } \\
\text { patriotism }\end{array}$ & - & $\begin{array}{l}\text { Horror } \\
\text { film }\end{array}$ \\
\hline $\begin{array}{l}\text { Background } \\
\text { sound }\end{array}$ & Crowd & $\varnothing$ & $\varnothing$ & Helicopters & - & $\varnothing$ \\
\hline \multicolumn{7}{|l|}{ Clinton } \\
\hline Genre & Dance & $\begin{array}{l}\text { Classical } \\
\text { Minimalism }\end{array}$ & $\begin{array}{l}\text { Classical } \\
\text { Minimalism }\end{array}$ & $\begin{array}{l}\text { Electronic } \\
\text { Drum\&Bass }\end{array}$ & $\begin{array}{l}\text { Electronic } \\
\text { Experim. }\end{array}$ & Dance \\
\hline $\begin{array}{l}\text { Mental } \\
\text { image }\end{array}$ & $\begin{array}{l}\text { Youthful, } \\
\text { modern }\end{array}$ & $\begin{array}{l}\text { Thoughtful, } \\
\text { insightful }\end{array}$ & $\begin{array}{l}\text { Thoughtful, } \\
\text { insightful }\end{array}$ & $\begin{array}{l}\text { Citizen } \\
\text { dynamism }\end{array}$ & Insightful & $\begin{array}{l}\text { Youthful, } \\
\text { modern }\end{array}$ \\
\hline Soundscape & $\begin{array}{l}\text { American } \\
\text { Dream }\end{array}$ & $\begin{array}{l}\text { American } \\
\text { Dream }\end{array}$ & $\begin{array}{l}\text { American } \\
\text { Dream }\end{array}$ & $\begin{array}{l}\text { American } \\
\text { Dream }\end{array}$ & $\begin{array}{l}\text { American } \\
\text { Dream }\end{array}$ & $\begin{array}{l}\text { American } \\
\text { Dream }\end{array}$ \\
\hline $\begin{array}{l}\text { Background } \\
\text { sound }\end{array}$ & Crowd & $\varnothing$ & $\varnothing$ & $\varnothing$ & $\varnothing$ & Crowd \\
\hline
\end{tabular}

\section{DISCUSSION AND CONCLUSIONS}

These results show clear differences in the strategic use of music in the two candidates' campaigns. In general, Trump's music campaign uses a low pitch, low rhythm and low intensity melody based on orchestral strings to create the mental image of crisis and depression, which, expectedly, will be challenged by Trump -namely the mental image of the savior of the nation. This is supported by the type of sound elements, the acoustic features and the genre of Trump's music. These elements refer to the American patriotism built by Hollywood films throughout the second half of the past century. The music employed in Trump's campaign is classical orchestral music, with string and wind instruments and drum rolls that closely refer to epic and military genres.

Moreover, the use of the helicopter effects in the first spot is very cinematographic and adds on the construction of American patriotism, war and action movies' imaginary. In this vein, the third spot's soundscape refers to a horror film to portray the mental image

\footnotetext{
${ }^{1}$ This spot uses the same music than the first one.
} 
of a nightmare, associated with Clinton. These knowledge structures are recognized by any western citizen so that the brand associations of the candidate are built on the values of the Hollywood hero: patriot, honest, brave, sensitive, human, and winner. In addition, this musical code activates identification and projection processes with the hero and the villain respectively so that the brand personality mechanism helps build the candidate brand.

By contrast, Clinton's campaign uses a high pitched, high rhythm and high intensity melody based on electronic sounds to build Clinton's brand as a dynamic modern women in a dynamic, modern, happy and free-of-complex society. Music in Clinton's third spot uses the crowd to include diversity as a brand value. In addition, the use of a sung voice in her presentation at the convention humanizes the brand, this is to say, the voice presents the candidate as an earthly emotional citizen. Voice represents the human individuality as it has the greatest harmonicity, which allows humans to recognize millions of voices. The subtlety, minimalism and complexity of voice as a sound element capable of distinguishing (and semiotically value) each human being contrasts with the extremism, maximalism and simplicity of wind and string instruments, with great pitch fluctuations, played in Trump's orchestral music

Although both campaigns use music to build their candidate brand through emotions, they do it differently. Trump's music does not solely prompt emotions, but it builds a human personality that in itself has emotions. In contrast, Clinton's music uniquely prompts basic emotions such as happiness, joy or fear, especially through high pitch and rhythmic genres such as the electro and dance music. In addition, Clinton's piano music reinforces the value of rationality given by the voiceover's timbre and content. In sum, Trump's musical code is direct and simple whereas Clinton's musical code is complex and indirect. Even when each candidate's music refers to each other, they do it in very different ways. Trump uses low pitched inharmonic sounds to refer to Clinton, while, Clinton uses a soft delicate piano song to create a sad atmosphere when referring to Trump's major sayings.

Trump and Clinton's brand associations are attained through intense brand experiences in the different touchpoints: convention, digital media and traditional media. However, their respective use of music is not only diametrically opposed in terms of values, but 
they differ in the branding strategy. Trump uses music to build its brand personality. This is a strategic objective in itself. Clinton uses music to add values to the rational strategy expounded by the content, thus music is not a strategic objective in itself.

Music branding can be used strategically to build political brands. As a powerful persuasive tool of the sound branding field, acoustic features can characterize music. These acoustic features are related to the semiotic significance of the music in the form of genres, mental images and soundscapes. In the case study of 2016 US elections, Trump brand and Clinton brand used music in their respective campaigns to raise key associations, namely American patriotism and war hero the former, and American values and tolerance the later. The great differences in the acoustic and semiotic parameters between the two candidates' music reinforce this conclusion. Therefore, music was used as a brand construct to conduct brand associations in what we call music branding.

However, the strategic use of music was not the same in Trump and Clinton campaigns. The role played by music in building the Trump brand was central while the role played by music in building the Clinton brand was merely complementary to other communication resources. Taken Trump as the paradigmatic case of music branding strategy, music was employed to build a brand personality through brand associations and brand experiences. Briefly, music by itself built the character of a hero taking action to save his patria. The potentiality of music to transmit brand values and create emotional experiences is the basis to interact and engage with the brand.

This study defines the acoustic and semiotic parameters of music to be taken into account when composing or selecting music for a campaign. These findings make progress on political branding strategies, especially brand associations, brand personality and brand experiences constructs. Moreover, these findings are coherent with previous analysis on the effects of auditory structural elements on brand attitudes (Potter \& Choi, 2006; Potter, Lang \& Bolls, 2008).

This study is not without limitations. Although its objective is to analyze the potential of music to create brand values, the qualitative analysis of a single case study implies a single point of view and thus it is insufficient to come up with conclusive findings. 
Rather, these findings can only be taken as a general model to be tested in future studies. What is more, the fact that the analysis has a high degree of interpretation weakens the predictive power of empirical results. By contrast, this study does articulate constructs from political branding and sound branding and embeds a coherent emerging field of research. In addition, the US elections are pioneering cases to conduct exploratory in-field studies on new trends.

Any study within this framework can be fruitful to gain insights on the field. Accordingly, the connections determined in this article between music and branding suggest a model for practitioners to design future political strategies and researches to test brand constructs within this line of research. On the basis of these findings, Aaker's crucial dimensions of brand personality building -sincerity, excitement, competence, sophistication and ruggedness- can be easily hypothesized in future studies on political music branding. The progress in branding constructs runs parallel to the use of communication strategies to conduct them. In this vein sound branding in general starts being used by corporations in many different touchpoints, especially with the advent of digital media and public relations. Music in particular adapts to this reality as an emotional, not invasive engaging code.

Finally, being such a strategic resource, music branding field is naturally comprised within the general comprehensive political public relations strategy. Presumably, Clinton's strategy strongly relied upon a more rational, minimalist, value-centered campaign in which paternalism and argumentative rhetoric were the pillars of her communication actions. In contrast, Trump's campaign was focused on an emotional, maximalist stereotyped campaign in which slogans and strong mental images were the pillar of his communication actions.

\section{REFERENCES}

Aaker, D. A. (1991). Managing brand equity: Capitalizing on the value of a brand name. New York, NY: The Free Press.

Aaker, D. A. (1996). Building strong brands. New York, NY: The Free Press.

Aaker, J. L. (1997). Dimensions of brand personality. Journal of Marketing Research, 34(3): 347-356. 
Aaker, J., Fournier, S. \& Brasel, S. A. (2004). When good brands do bad. Journal of Consumer research, 31, 1: 1-16.

Abeles, H., \& Porter, S. (1979). So your daughter wants to be a drummer? Music Educators Journal, 65(5): 46-49.

Alpert, M.I., Alpert, J.I., \& Maltz, L.N. (2005). Purchase occasion influence on the role of music in advertising. Journal of Business Research, 58: 369- 376.

Argo, J., Popa, M., \& Smith, M. (2010). The Sound of Brands. Journal of Marketing, 97-109.

Ballouli, K., \& Heere, B. (2015). Sonic branding in sport: A model for communicating brand identity through musical fit. Sport Management Review, 18(3): 321-330.

Belaid, S., \& Temessek Behi. A. (2011). The role of attachment in building consumerbrand relationships: an empirical investigation in the utilitarian consumption context. Journal of Product \& Brand Management, 20, 1: 37-47.

Boersma, P., \& Weenink, D. (2014). Praat: doing phonetics by computer [Software]. In: http://www.praat.org.

Bollue, S. (2015). Sonic Branding: a framework for understanding sound branding and an overview of its most notable practices across industries. Bachelor Thesis presented at the University of Applied Sciences, Haaga-Helia.

Bonde, A., \& Hansen, G. A. (2013). Audio logo recognition, reduced articulation and coding orientation: Rudiments of quantitative research integrating branding theory, social semiotics and music psychology. SoundEffects, 3, 1+2.

Brodsky, W. (2010). Developing a functional method to apply music in branding: Design language-generated music. Psychology of Music, 39(2): 261-283.

Bruner, G. C. (1990). Music, mood, and marketing. Journal of marketing, 94-104.

Cwalina, W., \& Falkowski, A. (2015). Political branding: political candidates positioning based on inter-object associative affinity index. Journal of Political Marketing, 14.1-2: 152-174.

Dubé, L., Chebat, J.C., Morin, S. (1995). The effects of background music on consumers' desire to affiliate on buyer-seller interactions. Psychology \& Marketing, 12(4): 305-319.

Farhana, M. (2012). Brand elements lead to brand equity: Differentiate or die. Information Management and Business Review, 4(3): 223-233.

Fournier, S. (1998). Consumers and their brands: Developing relationship theory in consumer research. Journal of consumer research, 24, 4: 343-373. 
Fox, W.S., \& Wince, M.H. (1975). Musical taste cultures and taste publics. Youth and Society, 7: 198-224.

Fuzellier, E. (1965). Le langage radiophonique. IDhec: Paris.

Gjerdingen, R.O., \& Perrott, D. (2008). Scanning the Dial: The Rapid Recognition of Music Genres. Journal of New Music Research, 37, 2: 93-100.

http://dx.doi.org/10.1080/09298210802479268

Gustafsson, C. (2015). Sonic branding: A consumer-oriented literature review. Journal of Brand Management, 22(1): 20-37.

Guzmán, F., Paswan, A. K, \& Steenburg. E. V. (2015). Self-Referencing and Political Candidate Brands: A Congruency Perspective. Journal of Political Marketing, 14, 1-2: 175-199.

Groves, J. (2007). A Short History of Sound Branding. In K. Bronner \& R. Hirt (Eds.), Audio Branding: Entwicklung, Anwendung, Wirkung akustischer Identitäten in Werbung, Medien und Gesellschaft, pp. 40-51, Munich: Reinhard Fischer.

Jackson, D. (2004). Sonic Branding. New York: Palgrave McMillan.

Jackson, D. M., \& Jankovich, R. (2013). Hit Brands: how music builds value for the world's smartest brands. Hampshire: Palgrave Macmillan.

Keller, K. L. (1993). Conceptualizing, measuring, and managing customer-based brand equity. Journal of Marketing, 57(1): 1-22.

Klink, R. R. (2000). Creating brand names with meaning: The use of sound symbolism. Marketing Letters, 11(1): 5-20.

Krishna, A. (2012). An integrative review of sensory marketing: Engaging the senses to affect perception, judgment and behavior. Journal of Consumer Psychology, 22(3): 332-351.

Krishnan, V., Kellaris, J. J., \& Aurand, T. W. (2012). Sonic logos: can sound influence willingness to pay? Journal of Product \& Brand Management, 21/4: 275-284. DOI $10.1108 / 10610421211246685$

Kosslyn, S., Ganis, G., \& Thompson, W. (2010). Multimodal images in the brain. In A. Guillot and C. Collet (Ed.), "The neurophysiological foundations of mental and motor imagery", pp. 3-16. Oxford Scholarship.

DOI:10.1093/acprof:oso/9780199546251.003.0001

Lantos, G. P., \& Craton, L. G. (2012). Model of consumer response to advertising music. Journal of Consumer Marketing, 29, 1: 22 - 42. DOI:

$10.1108 / 07363761211193028$ 
Machin, D. (2011). Towards a Social Semiotic Approach of the Analysis of Emotion in Sound and Music. The Public Journal of Semiotics, III(2): 152-174.

Miller, D.W., \& Marks, L.J. (1992). Mental Imagery and Sound Effects in Radio Commercials. Journal of Advertising, 21(4): 83-93.

MixMeister BPM Analyzer 1.0. (2016). URL: https://mixmeister-bpmanalyzer.softonic.com/

North, A. C., Hargreaves, D. J., \& McKendrick, J. (1999). The influence of in-store music on wine selection. Journal of Applied Psychology, 84(2): 271-276.

North, A. C., MacKenzie, L. C., \& Law, R. M. (2004). The Effects of Musical and Voice "Fit" on Responses to Advertisements. Journal of Applied Social Psychology, 34, 8: 1675-1708.

Nusselder, A. (2013). Twitter and the personalization of politics. Psychoanalysis, Culture \& Society, 18.1: 91-100.

Paivio, A. (1986). Mental representations: A dual coding approach. New York: Oxford University Press.

Park, C., \& Young, M.S. (1986). Consumer Response to Television Commercials: The Impact of Involvement and Background Music on Brand Attitude Formation. Journal of Marketing Research, 23: 11-24.

Parker, B. T. (2012). Candidate brand equity valuation: A comparison of US presidential candidates during the 2008 primary election campaign. Journal of Political Marketing, 11, 3: 208-230.

Potter, R.F. \& Choi, J. (2006). The Effects of Auditory Structural Complexity on Attitudes, Attention, Arousal, and Memory. Media Psychology, 8: 395-419.

Potter, R.F., Lang, A., \& Bolls, P.D. (2008). Identifying Structural Features of Audio: Orienting responses during radio messages and their impact on recognition. Journal of Media Psychology, 20(4): 169-178.

Rentfrow, P. J., \& Gosling, S. D. (2003). The do re mi's of everyday life: Examining the structures and personality correlates of music preferences. Journal of Personality and Social Psychology, 84: 1236-1256.

Reber, R., Schwarz, N., \& Winkielman P. (2004). Processing Fluency and Aesthetic Pleasure: Is Beauty in the Perceiver's Processing Experience? Personality and Social Psychology Review, 8(4): 364-382. 
Riding, D., Lonsdale, D., \& Brown, B. (2006). The effects of average fundamental frequency and variance of fundamental frequency on male vocal attractiveness to women. Journal of Nonverbal Behavior, 30(2): 55-61.

Roles, J. (2010). Forming Soundmarks: A Critical Evaluation of the Sonic Brand within the Contemporary Mediascape. Thesis presented at the Scchol of Humanities and Social Sciences, University of East London.

Rook, D. W. The ritual dimension of consumer behavior. Journal of Consumer Research, 12, 3: 251-264.

Schaffer, Murray (1979). Le pysage sonore. Jean-Calude Lattés: Paris.

Schmitt, (2012). The consumer psychology of brands. Journal of Consumer Psychology, 22: 7-17. DOI:10.1016/j.jcps.2011.09.005.

Schwartz, D. L. (1999). Physical imagery: kinematic versus dynamic models. Cognitive Psychology, 38(3): 433-64. DOI:10.1006/cogp.1998.0702

Simmons, R. (2005). Music Branding-What's the Real Score? Music-Equity. SongSeekers Co, 6-10

Spence, C. (2008). Auditory product design: New methods for evaluating the influence of changes in product sound on product evaluation. Proceedings of the Institute of Acoustics, 30(4): 31-38.

Spence, C. (2012). Managing sensory expectations concerning products and brands: Capitalizing on the potential of sound and shape symbolism. Journal of Consumer Psychology, 22(1): 37-54.

Spence, C.; Shankar, M. U. \& Blumenthal, H. (2010). 'Sound bites': Auditory contributions to the perception and consumption of food and drink. In F. Bacci \& D. Melcher (Eds.), Art and the senses, pp. 207-238, Oxford: Oxford University Press.

Murphy, L., Schurmann, A., \& Moscardo, G. (2013). Building Brand with Music: Australian Cases. In P. Tschmuck, P. L. Pearce and S. Campbell (Eds.), Music Business and the Experience Economy, pp. 153-174, Springer. DOI 10.1007/9783-642-27898-3_10

van Leeuwen, T. (1999). Speech, music and sound. MacMillan Press.

Venkataraman, A. (2007), The Sonic Boom: Effect of Logo Presentation Style in Television Commercials on Memory for the Advertised Brand. Master thesis presented at the Journalism Department, University of Missouri. 
Vorster, I. A. (2015). The influence of sonic logos in television advertisements: a neuromarketing perspective. Thesis presented at the Faculty of Business Management at Stellenbosch University [online]. URL: http://scholar.sun.ac.za/handle/10019.1/97892

Whan Park, P., Macinis, D. J., \& Priester, J. (2006). Brand Attachment: Constructs, Consequences, and Causes. Foundations and Trends in Marketing, 1, 3.

Winkielman, P., Schwarz, N., Fazendeiro, T. A., \& Reber, R. (2003). The Hedonic Marking of Processing Fluency: Implications for Evaluative Judgment. In "The Psychology of Evaluation: Affective Processes in Cognition and Emotion”, J. Musch \& K.C. Klauer (Eds), pp. 189-217, Mahwah, NJ: Lawrence Erlbaum. Zander, M. F. (2006). Musical influences in advertising: how music modifies first impressions of product endorsers and brands. Psychology of Music, 34(4): 465480 .

Zhu, R., \& Meyers-Levy, J. (2005). Distinguishing between the meanings of music: When background music affects product perceptions. Journal of Marketing Research, 42, 3: 333-345.

\section{AUTHOR BIOGRAPHIES}

Lluís Mas, $\mathrm{PhD}$, is a visiting professor of advertising and sound production in the Department of Communication, at the Pompeu Fabra University (Barcelona, Spain).

Maria-Rosa Collell, $\mathrm{PhD}$, is a senior lecturer of public relations and event management in the Department of Linguistic and Communication of the University of Girona (Spain).

Jordi Xifra, $\mathrm{PhD}$, is a professor of corporate communication and public relations in the Department of Communication, at the Pompeu Fabra University (Barcelona, Spain). 